\title{
Artigo
}

\section{From Farmers to Firms: United States and China in a Shifting World Order}

\section{Dos Fazendeiros às Firmas: Estados Unidos e China numa Ordem \\ Internacional em Transformação}

Carlos Frederico Pereira da Silva Gama ${ }^{3}$

Fernando Furquim de Camargo ${ }^{4}$

DOI: 10.5752/P.1809-6182.2018v15.n2.p11

Recebido em: 06 de setembro de 2018 Aceito em: 04 de novembro de 2018

\section{Abstract:}

Ten years after the crisis, contradictions of a globalized capitalist economy rear their heads. The trade war between US and China provides surprising insights on its reorganization. China, an industrial powerhouse, claims respectability as an indispensable stakeholder in international regimes, as a challenged US retreats behind protectionism and punishing bilateralism.

Key-Words: United States, China, globalization

\section{Resumo:}

Dez anos após a crise, contradiçóes da economia capitalista globalizada se tornam mais visiveis. A corrente disputa comercial entre EUA e China fornece elementos surpreendentes de sua reorganização. A China, potência industrial, demanda respeitabilidade como parte indispensável nos regimes internacionais, enquanto os EUA se retrai em protecionismo e bilateralismo punitivo.

Palavras-chave: Estados Unidos, China, globalização

3. PhD in International Relations, PUC-Rio. Visiting Professor, Al Akhawayn University in Ifrane (Morocco). Professor of International Relations, Universidade Federal do Tocantins. ORCID: 0000-0003-2982-6693.

4. PhD in Economic History, Universidade de São Paulo. Professor of International Relations, Universidade Federal do Tocantins. ORCID: 0000-0002-0178-0833. 


\section{Prologue: the Magic Spell is Overdue}

In the words of Charles Kindleberger (1981), the US took the burden of providing postwar public goods to economies in reconstruction. At the same time, if benefited from two decades setting the pace of Western economies. Between the dollar-as-anchor and dollar-as-export, there was a net surplus.

Comes Nixon and Détente, petrodollars, European Economic Community and Japan saying "no". The untangling of Bretton Woods arrangements furnished the US with a more flexible environment in order to face USSR amidst a slowdown. Interest rates skyrocketed and the dollar regained some of its gravitational pull. By mid1980s, John Lewis Gaddis (1986) was speaking of a "long peace" of coexistence and its dividends. Seemingly, the US learned to adapt to a changing Cold War environment. However, as the Soviet Empire receded, policymakers were less sure about what to do next.

At the end of Cold War, US political economy retained its mainlines, more and less what it has done before. Reliance on multilateral institutions spilled over from the falling walls between Berlin and the Urals. However, with no existential threat at sight, new normative investments were postponed for a distant age, during the "unipolar moment" depicted by Krauthammer (1991) and Wolfforth (1999). Dictatorships in Iraq and North Korea could be "funneled" through already available channels. Buck-passing begun early on, with Milosevic's Serbia franchised to NATO and the young European Union. The very idea of a rival power paled next to apathetic attempts by Boris Yeltsin to liberalize Russia.

9-11 remains a guilty pleasure, inasmuch as it fostered a coherent narrative for the fall of optimism, with steady pathos. The next century be- gun with acrid smoke, flaming towers and Osama Bin Laden. Still, there was the issue of late-1990s globalization. Waves of financial crises in emerging economies challenged the early 1990s apologetics of an affluent world without borders like a disquieting tsunami.

This is the background of the first George W. Bush administration, after the surprising defeat of Al Gore. A minimalistic approach to multilateralism had already become the order of the day. Regaining such a ground would prove a hard task, afterwards.

Comes 2008. The deepest economic crisis since the Crash shakes the already contested foundations. Was there a future for Bretton Woods after the beggar-thy-neighbor panic-stricken spree? You could place your brightest bets on China and the BRICS, as a renewed wave of emerging economies rose to the forefront, for a while. However, magic formulae are nowhere to be see, a decade in the making.

Two sets of expectations roamed the landscape of 2008's aftermath.

Firstly, President Barack Obama would bring the economy back in track. This ambition could not be compromised at any cost. Secondly, an affluent global economy would make this task easier. The push from emerging countries would provide more than a rude awakening.

By 2016, only one of those expectations was fulfilled. Even this proved not enough to assure the Democrats another mandate. Bewildered by Obama's economic performance, Hillary Clinton cast a blind eye to Donald Trump's fortunes simmering behind the scenes.

In a sluggish global economy, emerging powers no longer pulled in the bets. As old cards remained underwhelming, the US recovery seemed short-lived - unless it could prevail in zero-sum games.

In retrospect, the rise of Trumpism seems less improbable, almost anticlimactic. 


\section{Introduction: America Great Again?}

In July 23 2018, President Donald Trump hosted a "Made in America" day in the gardens of White House (BREUNINGER, 2018). Days after, statistics revealed that US' GDP grew 4.1\% during the last 3 months (CHANDRA, 2018). Gathered in Johannesburg, the emerging countries of BRICS condemned "protectionism" (Xinhua, 2018). After all the Helsinki turbulences, Trump ended the week riding an unsuspected triumph, avoiding an agricultural clash with the European Union (BBC, 2018). As the Shanghai Stock Exchange plummeted following another round of retaliations, his "Make America Great Again" motto seemed vindicated.

However, there is more to this picture than meets the eye.

During the previous week, Trump was an easy target due to his promised aid package to farmers. The figures (U\$ 12 billion) are not that impressive (SALAMA \& BUNGE, 2018). They represent roughly half of the amount of aid programs already in course since the Great Depression (Reuters, 2018a). Apart from placating the depressed state of farmers in America, (one of his assets in 2016, and 2018 is election year), Trump also responded to Chinese retaliation for unilateral tariffs - but imposed on industrial products. Re-elected President Xi Jinping quickly reacted to the $\mathrm{U} \$ 50$ billion tariff package (which, allegedly, could reduce China's growth by $0.2 \%)$ by targeting US commodities. This was the first noticeable crack on Trump's protectionist walls.

Fear of a massive trade war between the world's largest economies occupied WTO's agenda across 2018 (TAN, 2018). A familiar picture from the days before GATT, not to mention the interwar period. Even this said there is something new among those anxieties and reminiscences. A striking novelty.

\section{The 2008 Crisis and a Shifting World Order}

The 2008 financial crisis was a turning point in international relations. It meant the culmination of a prolonged deadlock in multilateral institutions. It affected debates on the distribution of power in the international system, as well as on mechanisms of international governance. In the wake of the crisis, the contradictions of a globalized capitalist economy, which had asymmetrically grown for decades (for most of times, preserved from contestations) reared their heads. Economic rise moved emerging countries from the fringes to the center of debates on international governance. Such countries, with their own development models running on for decades, belatedly got under the spotlight.

After 2008, China rose to the top of industrial economies. Later on, a challenged US elected a real estate tycoon on behalf of rust belts and falling commodity prices. Trump's drive away from international norms, towards protectionism was predictable (even in 2016).

However, shockwaves remain regarding the profiles of major economies. In the current trade war, China targeted farmers and the US, firms. This unprecedented reversal of roles see an emerging Global South at the helm of a shifting world order, in which globalization thrives and crumbles.

The Chinese economy accomplished a dual feat in the course of 70 years (the lifespan of USSR). Firstly, it made the transition from a rural economy to an urban industrialized one, with a handful of hundred million people moving across the former "Middle Empire". Secondly, in order to propel a nascent industry, China gradually become the backbone of regional productive chains. This kind of integration was much less reliant on normative convergence than in Europe. It left plenty of space 
for discretionary national policies. Pragmatic amalgamation stems from attuned political leadership.

One example of such pragmatism is China's $21^{\text {st }}$ century conception of "duojihua" - translated by $\mathrm{Li}(2002)$ as "multipolarization" or "asymmetric diplomacy". With a strategic emphasis on regional settings and contrasting with Western conceptions that stress the destructive character of anarchy (a competitive environment ruled by self-help behavior), duojihua postulates that there is no single predominant or hegemonic country: all countries have roles and duties in the system. Duojihua also invokes a posture of tolerance and understanding between different cultures and polities (Ibid., p.4).

Departing from multilateralism as conceptualized by Ruggie (1993), China allows the flexibilization of principles held to be indivisible, breaking with diffuse reciprocity. A relative loosening of norms follow in terms of accommodating different international circumstances. China (and other BRICS) also substitutes market forces by the state as the driver for globalization transitions - "liberalization under state rule" (JAIN, 2006, p. 103).

All this took place within a socialist revolution, which afforded incremental changes. The impressive rise of China did not equal the spread of liberal values - a post-Cold War tenet made famous by Fukuyama (1992). The Chinese regime remains encapsulated from foreign influence and from the pushes and pulls of a vibrant civil society.

Taking into account those complexities, the Trump administration ceases to be an exceptional event and falls within the realm of the predictable - a world in which the precedence that the US enjoyed after the fall of Berlin Wall seems no longer assured, as proposed by Kupchan (2012). The self-professed master of "the deal" dwells in expected moves after all those seismic shifts: strong leadership meets economic protectionism.
At the wake of the crisis, there were widespread expectations that emerging countries would infuse some vitality in a highly contested system (including major institutions lacking representativeness and efficiency). Among them, the BRICS group gathered most attentions, as those countries were growing faster than developed economies in the aftermath of the crisis. Do the 2018 contradictions vindicate the rise of BRICS? Is there room for optimism - in the words of Stuenkel (2016) regarding a post-Western world? This seems hardly the case.

Firstly, the international financial architecture proved arguably more resilient (DREZNER, 2014) than the swan songs of 2008 could afford. Its main features are still recognizable. Among BRICS only China (and India, to some degree) delivered the goods predicted ten years after. Collectively, those emerging countries did not departure significantly from their pre-2008 patterns of engagement.

That brings our attention to China, where growth rates fell during the last decade - from an average of more than $10 \%$ before the crisis to $6-7 \%$ since $\mathrm{Xi}$ Jinping's ascension to the Party's leadership (GAMA, 2018a). That China accommodated in a lower plateau is not necessarily surprising: its unparalleled growth hold steady for three decades. However, there is a distinction between a mature economy that reaches stagnation (Japan since 1990s, EU members) and an emerging one facing a systemic crash.

China adopted a liquidity shock to avoid any major meltdown of its economic model (running on since the late 1970s). At the same time, Chinese firms (many of them with significant government input) broadened their operation basis, from regional to global productive chains - a movement allowed in part by the crisis. In this sense, even though China becomes more global after the crisis, the country did not depart significantly from its own national platform. 
Under Jinping, Chinese economy faces a slower growth and the hazards of subpar demand with attempts to "fight corruption" and "promote austerity". It will not necessarily lead to the weakening of government's input in Chinese economy. It also means more international partners will be affected by the decisions in Beijing. With more interdependence, there goes more vulnerabilities. China remains a key player in a number of regimes, which makes more unlikely that they will change soon.

First among unequals, the sole emerging economy able to challenge the US is now in a surprising position - it has become a beacon of the status quo. China's $21^{\text {st }}$ century "peaceful rise" was defined by Wang (2005) as a comprehensive long-term strategy, leveraging globalization as a catalyst, in order to accelerate China's economic development and elevate its power and stature. Such rise must secure a peaceful international environment to sustaining economic development, augmenting Chinese power by ensuring stability in its surroundings, avoiding a premature showdown with the US (WANG, 2011, p. 442). As Jinping pays more than lip service to "free trade" at the WTO and offers its goodwill in international forums, Trump gets entrenched in protectionism and jingoistic rhetoric, further estranged from traditional allies. This configuration rewards long-term Chinese policies.

The diversification of the Chinese economy was favored by the growing interdependence of a still affluent world economy.

With Trump fighting to increase the average national content of "made in US" product above $60 \%$, foreign firms amass considerable stakes. The situation falls squarely in place with the rise of China, where local firms benefit from spinoffs of topnotch technology by speeding technological breakthroughs. As the scale of the Chinese economy furnishes more than enough reasons from further enmeshment by neighbors, the country reaps the fruits of interdependence relatively safe from tariff harms. On the other side, Mike Pence's hometown already bears the scars of escalating trade fistfights (POGRUND, 2018).

China's comfortable position also translates in terms of less pressure with regard to global norms. Confident in the gravitational pull of his burgeoning economy, Jinping can afford the property rights critique with a smile upon his face, the same used to advocate "free trade" when the occasion calls for (MBATHA \& BAX, 2018).

Under Trump, the US economy relies even more on consumption. Interest rates fell to the ground, in the Reaganite belief (BLANCHARD, 1987) that relieved consumers will sustain economic growth long enough for it to trickle-down to other sectors, as trade wars set in their alleged benefits. Protectionism belongs in this dreamworld of autarchy as a fundamental part, not as an impromptu abnormality.

At the BRICS summit in Johannesburg, South Africa, fellow leaders joined Jinping in a cautious condemnation of protectionism. However, inter-firm ties remain modest among the group. BRICS still provide an adequate vehicle for a rising China. Apart from raising awareness on imbalances and inequalities of the multilateral architecture, the group provides room for the socialization of their respective leaderships. The kind of articulation favored by those emerging countries relies on top-level political conciliation and state-driven economic concessions at the bottom (Reuters, 2018b). There are limits to those strategies, so China will entertain other options at the regional and the global levels.

\section{The Trump Doctrine in a ceteris paribus world}

Trump's uneasy mix comprises a two-pronged strategy. He mobilized the Reagan textbook to 
bring about a massive tax cut - especially in corporate income, property and sales. A consumption push helped the 4\%-plus GDP increase just before the mid-term elections. However, it also put additional pressure on the US economy, among falling commodity prices and industrial stagnation. On the other hand, shutting the door on China allows room for agricultural accommodation with the $\mathrm{EU}$ (already under pressure on at the security front, with Trump's attempts on NATO burden sharing).

Striking a deal on recalcitrant NATO allies through trade seems a surprising move (at the shadow of the Turkish case, a prophylaxis of doubtful efficacy). However, it was one more campaign promise fulfilled by the embattled administration.

Increasingly reliant on foreign commodities, China cannot cast a blind eye to the Trumpist agenda. In asymmetrical deals all over the globe, it broadened its palette by offering selective access to its massive market. As Chinese firms consolidate their profiles, such concessions become more unlikely. Therefore, Jinping shifted gears towards FDI. Apart from providing leverage for Chinese firms (COZZA, RABELLOTTI \& SANFILIPPO, 2014), such a move proved another hurdle in relations with the US.

Trump seeks his "resurgent America" prophecy by implementing more stringent regulations on high technology and infrastructure, combined with a doctrine of shrinking multilateralism. Amidst intensified political tensions between the contested superpower and other parts of the world, this strategy seems short-lived. In a world of walls and soft on law, the US and China would be fighting for the same markets, increasingly chained in divergent investment strangleholds. This said, another sign of a shifting world rears its head. Trump's ceteris paribus logic (GAMA, 2017) operates at the national level, whereas Jinping's logic would unequivocally be running at regional ones. In terms of legitimacy, this kind of balance favors the Chinese side, less impinged by former promises and less prone to break them.

Comparisons in a country-by-country basis also show competitive advantages for the East. The Chinese economy slowed down since the crisis, but it remains among the world's prime movers. Under Jinping, China become less unequal (GAMA, 2018a). His crackdowns on corruption proved pivotal in his party leadership, not to mention popular acclaim. Fighting his own party, Trump remains a beleaguered, polarizing figure. The US economy only recently recovered from the crisis, still lagging behind other G20 members and dealing with rising inequality. In this sense, a possible defeat at midterm elections could prove the nadir to a contested administration, suffocated by multiple investigations.

The Trumpist foreign agenda unfolds according to a division of the labor. Diplomatic stunners in the Korean Peninsula and the Middle East, Russian ambivalence (TRAUB, 2018), bemusement across the Atlantic, courting India and no love lost on China. The POTUS provided a few underpinning cliffhangers for this disparaging assembly line. Burden sharing replaces the provision of public goods to traditional allies, a course of action that Kindleberger anticipated, with astounding allure, roughly 40 years ago:

And the country with, let us say, rising imports as it struggles to keep markets open, an overvalued exchange rate as it accepts the devaluations of others, an undue share of the burdens of NATO or of foreign aid, begins to concern itself with the free rides of others and talk of more equitable burden-sharing (KINDLEBERGER 1981, p. 250).

Those alleged savings at external fronts are repatriated as investments for making "America great again". This provides another swansong for multilateralism, as defined by Ruggie (1992). Diffuse reciprocity seem all at odds with the selec- 
tive charms of the "art of the deal". The notion of shared principles - including nondiscrimination fall short in new particularistic ordeals.

Trump's nationalist brand of choice relies on entwined notions of Fortress America and gated communities. Not surprisingly a Brexit pundit, the POTUS sees no big fuss in setting immigrant children apart from their imprisoned parents and insists in getting from Mexico a border wall. Nevertheless, the Trump doctrine is fundamentally at odds with the affairs of US firms, which extract significant portions of their profits from abroad 5 . He seems more worried about halting acquisitions of US firms by Chinese investors (through regulatory bodies) than in finding opportunities overseas (DAVIS, 2018).

Additionally, In Trump's world, Africa and Latin America are notable absentees and a dimmer US soft power unveils windows of opportunity for emerging powers daring enough. Brazil used to be a good bet for second-tier leadership in Latin America and the Global South - just not now (GAMA, 2018b). In this regard, China makes the move of proving the next-best choice for leadership in a turbulent world.

\section{Beyond Trump's world: Chinese lessons for the status quo}

If interest groups hijacked Trump's agenda, China affords a surprising move: the socialist regime created by a peasants' revolution is now ruled by captains of industry, at the helm of a burgeoning capitalist enterprise. In this context, Trumpist tit-for-tat provides a winning combination for the Chinese. They can count on other rural powerhouses (as Brazil) to compensate for US restrictions and reap industrial rewards elsewhere. China has 5. Google, for example, controls $90 \%$ of the European market. become the major trading partner of BRICS and other countries at the developing world, where asymmetrical diplomacy fuelled by FDI thrives on.

Since 2008, prospects of a long-lasting liberal multilateral order seem more blurred than assured. The positioning of those countries that become the BRICS seemed less than obvious. Instead of acting like an aggrieved victim, China claimed a responsible great power status by acting "increasingly like one" (WANG, 2011, p. 442). Whereas China used to distrust multilateralism in fear that its institutions could be used to constrain or punish, Chinese leaders recognized that engagement with multilateral institutions fosters trade and security interests and limits US power. China is more aware that its rise has consequences for the Asia-Pacific region and beyond. Moreover, it becomes more interested in actively shaping regional affairs.

This renewed institutionalism is often fuelled by the diffusion of domestic norms to third partners through international institutions (RAMAMURTI \& SINGH, 2009, p. 150) - this process allows the flexibilization of norms. Emerging countries successfully made their transition to post-Cold War globalization according to an inward perspective rather than adopting a clear-cut openness (JAIN, 2006, p. 103). Such inwardness (including anti-cyclical economic recovery programs) was eventually extended to global settings.

The Chinese offensive put Xi Jinping at the unusual role of spokesperson for the status quo. At home, fighting corruption made the re-elected president widely popular with a rising urban middle class. It also did no harm to his dominance in higher echelons of the party: a Constitutional amendment now allows for indefinite re-elections. Abroad, Jinping embodies China's claim for respectability as an indispensable stakeholder in major international regimes (GAMA, 2018a). This rising power benefits from the limitations of current 
institutions. It has only slight incentives to devise new institutions or embark in renewal crusades. Therefore, this China advocates "freer trade" at the WTO and pushes for "sovereignty and cooperation" at the UN, as well as propagates a "greener economy". The writing on the wall is no need to fix what is not already broke.

Among neighbors, China experiences no great normative pressures. Fine-tuned by long-lasting leaders, ad hoc agreements entangled the major suppliers for the better part of the century. In labor-intensive economies, trade unions and legislation remain in a precarious position. America faces a hard competition with very few friends and innovation becomes one of its last few assets. This may be one of the major drivers behind Trump's wreaking havoc in the multilateral system (VESPA, 2018).

\section{Paradoxes of Globalization}

In the last 12 months the US become embroiled in 28 out of 38 dispute cases in WTO (WTO, 2018). Far from an unsuspected sign of institutional commitment, those disputes map the ongoing employment of the "art of the deal" wreaking havoc in a convoluted multilateral system. Firstly, it is noticeable that the disputes spurred by the US (8 out of 28) involve two members of the BRICS group (China and Russia), two NAFTA members (Canada and Mexico), apart from Turkey and the EU (NATO comes to mind). Secondly, skirmishes with traditional allies (Canada, Mexico EU, South Korea) represent $40 \%$ of disputes and provide early hints of discomfort ("trade remedies", "certain measures") on the way to selective dismantling of multilateral ties. In October, Trump celebrated a "wonderful trade deal" with Canada and Mexico - USMCA, a trimmed-down version of NAFTA (ZUMBRUN, 2018). The lion's share, however, goes to China. 7 out of 28 disputes concern the unilateral imposition of tariffs, additional duties on Chinese of US products and other measures.

The US was already China's major trading partner since the early 1990s. China become US' major trading partner under Jinping, with numbers reaching 500 billion dollars. The spiral of sanctions not only raises political sensibilities - they plunge into significant economic loss.

Trump's first wave of sanctions - 34 billion dollars in July 6 (LYNCH, PAQUETTE \& RAUHALA, 2018) - triggered a wave of retaliations that now impinges on roughly half of Chinese imports and exports to US - 250 billion dollars. The Chinese retaliations amount to little more than 110 billion dollars.

Apart from statistical disparities, there is a noticeable focus in the set of US measures adopted in favor of a handful of industrial sectors. They include the automobile industry, semiconductors (enmeshed with military disputes with both China and Russia), solar panels, washing machines, photovoltaic products. Chinese retaliation, on the other hand, focused commodities - ranging from pork and soybeans to steel and aluminum - which hit directly the electoral basis of the real estate tycoon turned POTUS before the mid-term elections.

The ripple effects of punishing bilateralism spill over to supply chains all over the world, in a global economy that is experiencing further slowdown in the second semester of 2018 (MAYEDA, 2018). Setting aside the impacts on a still-recovering world economy, trade retaliations will also trigger a ripple effect in American manufacture. Steel, iron, aluminum import cuts will arguably benefit local producers, at the expenses of consumers. Retaliatory tariffs will significantly affect other sectors of economy, not to mention stock markers. Relieving consumers, bringing industrial jobs back to US and shredding multilateralism are reliable sources of votes. Any incumbent electoral 
rewards are burdened with side-effects, non-sustainable at the long run.

\section{Final Remarks}

The ongoing trade war between Trump's US and Jinping's China provides another insight on the reorganization of a global capitalist economy after a major crisis.

In spite of modest reforms (such as vote rights in IMF), the launching of BRICS institutions such as the New Development Bank and the presence of high representatives from emerging countries in key roles in major institutions (such as WTO), major institutions remain stacked by the same problems that were highlighted ten years ago (EICHENGREEN, 2016). Multilateralism suffers the most and emerging countries did not provide comparable alternatives up to now. Do they need to do so? Instead of a changing of the guard (from Atlantic to Pacific) or the broadening of a club of developed economies, we had a set of centrifugal national strategies, which contributed to turbulence in world politics.

Instead of posing a direct challenge, a rising China goes for flanks with selective concessions and asymmetric diplomacy. US punishing bilateralism under Trump is no match, though its antics up the ante (and turbulence). The most noticeable feature of this dispute is the reversal of roles, with Trump appealing to US farmers and China strengthening its industrial policies.

Trump is making justice to his campaign rallies in which he affirmed that China was "ripping" the US economy. The selective dismantling of multilateral institutions in search of a "fair ground" for bilateralism, however, indicates a broader policy with systemic implications. The fallout of the 1945 institutional architecture unveils its inadequacy for the currently US administration but also says more than that: the guarantor of the system for ages now acts as a newly industrialized economy. At the background of a decreasing profile in world economy, "Make America Great Again" conveys a retreat.

The table has turned. Newcomer China is now the spokesperson of multilateralism and free trade. In 2018, China become the largest contributor to world's GDP growth - even though the rhythm of the Chinese economy slowed down from its early-2000s peak (China Daily, 2018a). The Chinese leadership increased its efforts in different corners of the world, carrying alongside the FDI flag. It reaffirmed its current investments in Africa and it reminded the incoming Brazilian government of the scope and depth of Chinese investments in Brazil, ostensibly contrasting those assets with the liabilities of a "tropical Trump" route (China Daily, 2018b).

This reminder contained a clear-cut rendition of Duojihua with the thrill of novelty. On the flipside of this coin, the Trump administration - at odds with this unintended turbulence in world politics (ROSENAU, 1992) - dwells in nostalgias of autarchy by decree.

By investing in bilateral talks with recalcitrant allies bursting "new" markets for US products, Trump basically reproduces the Chinese strategy without the allure. This is as far as one can get from a "level playing field". In a multilateral wasteland we may feel better at first sight, but the next few rounds seem nasty, brutish and with grim implications. Begging thy neighbors induce fewer friends, not to mention a world of competitive scarcity.

Now a gatekeeper to regional settings, China found different ways to cope with crisis. Duojihua seems more and more adequate to describe this shifting world order. Even among BRICS, we see emerging patterns of a new international division of labor. One hundred years ago, International Relations was dealing with a scenario with impressive similarities (LENIN, 1916). 


\section{References}

BLANCHARD, O. J. Reaganomics. Economic Policy, Vol. 2, Issue 5, 1, p. 15-56, 1987.

BREUNINGER, K. Trump hosts showcase of 'Made in America' products. CNBC, July 23 2018. Retrieved from: <https:// www.cnbc.com/2018/07/23/watch-trump-hosts-showcase-of-made-in-america-products.html>. Access in: September 1 2018.

CHANDRA, S. US Growth Hits 4.1\%, Fastest Since 2014, in Win for Trump. Bloomberg, July 27 2018. Retrieved from: <https://www.bloomberg.com/news/articles/2018-07-27/u-s-gdp-growth-hits-4-1-fastest-since-2014-in-win-for-trump >. Access in: September 12018.

Chronological list of dispute cases. WTO, November 22018. Retrieved from: <https://www.wto.org/english/tratop_e/dispu_e/dispu_status_e.htm>. Access in: November 12018.

COZZA, C. RABELLOTTI, R. \& SANFILIPPO, M. The impact of outward FDI on the performance of Chinese multinationals. BOFIT Discussion Papers 24/2014, April 122014. Retrieved from: <https:/helda.helsinki.fi/bof/bitstream/handle/123456789/13479/dp2414\%5B1\%5D.pdf?sequence=1 >. Access in: September 12018.

DAVIS, B. Trump Plans New Curbs on Chinese Investment, Tech Exports to China. Wall Street Journal, June 242018. Retrieved from: <https://www.wsj.com/articles/trump-plans-new-curbs-on-chinese-investment-tech-exports-to-china-1529883988>. Access in: September 12018.

DREZNER, D. W. The System Worked. How the World Stopped another Great Depression. Oxford: Oxford University Press, 2014.

EICHENGREEN, B. Hall of Mirrors: The Great Depression, the Great Recession, and the Uses - and Misuses - of History. Oxford: Oxford University Press, 2016.

Factbox: USDA's $\$ 12$ billion farmer relief package. Reuters, July 24 2018a. Retrieved from: <https://www.reuters.com/article/us-usa-trade-farmers-factbox/factbox-usdas-12-billion-farmer-relief-package-idUSKBN1KF053>. Access in: September 12018.

FUKUYAMA, F. The End of History and the Last Man. Los Angeles: Avon Books, 1992.

Full text of BRICS Summit Johannesburg Declaration. Xinhua, July 27 2018. Retrieved from: <http://www.chinadaily.com.cn/a/201807/27/WS5b5a7e22a31031a351e90845. html>. Access in: September 12018.

GADDIS, J. L. The Long Peace: Elements of Stability in the Post-war International System. International Security, Vol. 10, No.4, p. 99-142, 1986.

GAMA, C. F. P. da S. A Ceteris Paribus World? Economic Nationalism in the Age of Donald Trump. Medium, March 3, 2017. Retrieved from: <https://medium.com/@CarlosFre-
dericoPdSG/a-ceteris-paribus-world-economic-nationalism-in-the-age-of-donald-trump-47c358530b3c>. Access in: September 12018.

GAMA, C. F. P. da S. As reeleiçóes de Vladimir Putin e Xi Jinping numa ordem internacional em transformação. SRZD, March 22 2018a. Retrieved from: <http://www.srzd.com/ge$\mathrm{ral} /$ reeleicoes-vladimir-putin-xi-jinping-ordem-internacional-transformacao/>. Access in: September 12018.

GAMA, C. F. P. da S. Arrested Development - Brazil in a World in Crisis, 2008-2018. E-IR, May 11 2018b. Retrieved from: <https://www.e-ir.info/2018/05/11/arrested-development-brazil-in-a-world-in-crisis-2008-2018/>. Access in: September 12018.

JAIN, S. C. Emerging Economies and the Transformation of International Business - Brazil, Russia, India and China (BRICs). Northampton: Edward Elgar, 2006.

KINDLEBERGER, C. P. Dominance and Leadership in the International Economy - Exploitation, Public Goods, and Free Rides. International Studies Quarterly, Vol. 25, No. 2, p. 242-254, 1981

KRAUTHAMMER, C. The Unipolar Moment. Foreign Affairs, Vol. 70, No. 1 - America and the World, p. 23-33, 1991. KUPCHAN, C. A. No One's World - The West, the Rising Rest, and the Coming Global Turn. Oxford: Oxford University Press, 2012.

LENIN, V. I. Imperialismo - Etapa Superior do Capitalismo. São Paulo, Global, 1916/1979.

LI, N. China's Foreign Policy Agenda and the PLA's New Mission. RSIS Working Papers, 2002. Retrieved from: http:// www.rsis.edu.sg/rsis-publication/rsis/528-chinas-foreign-policy-agend/\#.VbKuF_lViko. Access in: September 12018.

LYNCH, D.J.,PAQUETTE, D. \& RAUHALA, E. U.S. levies tariffs on $\$ 34$ billion worth of Chinese imports. Washington Post, July 6 2018. Retrieved from: < https://www. washingtonpost.com/world/trumps-trade-war-with-china-is-finally-here--and-it-wont-be-pretty/2018/07/05/0e43048c-802c-11e8-b9f0-61b08cdd0ea1_story.html?utm_term=. a3012a3f2e18> . Access in: September 12018.

MAYEDA, A. Not So Fast for World Growth. Bloomberg, October 2 2018. Retrieved from: <https://www.bloomberg. com/news/articles/2018-10-02/not-so-fast-for-world-growth>. Access in: November 12018.

MBATHA, A. \& BAX, P. China's Xi Calls for BRICS to Reject Protectionism 'Outright'. Bloomberg, July 262018. Retrieved from: <https://www.bloomberg.com/news/articles/2018-07-26/china-s-xi-calls-for-brics-to-reject-protectionism-outright>. Access in: September 12018.

China to remain major contributor to global GDP growth. China Daily, October 30 2018a. Retrieved from: < http:// www.chinadaily.com.cn/a/201810/30/WS5bd7c3a7a310eff30328568e.html>. Access in: November 12018. 
No reason for 'Tropical Trump' to disrupt relations with China: China Daily editorial. China Daily, October 29 2018b. Retrieved from: <http://usa.chinadaily.com.cn/a/201810/29/WS5bd702e9a310eff303285424.html >. Access in: November 12018.

PARTINGTON, R. Trump hails 'wonderful new trade deal' with Mexico and Canada'. The Guardian, October 1 2018. Retrieved from: < https://www.theguardian.com/us-news/2018/ oct/01/trump-hails-wonderful-new-trade-deal-with-mexico-and-canada >. Access in: November 12018.

Petrobrás busca ampliar mercado na China com novo tipo de petróleo. Reuters, July 27 2018b. Retrieved from: <https:// economia.uol.com.br/noticias/reuters/2018/07/27/petrobras-busca-ampliar-mercado-na-china-com-novo-tipo-de-petroleo.htm>. Access in: September 12018.

POGRUND, G. Dependent on trade, Mike Pence's hometown takes a hit due to Trump's tariffs. Washington Post, July 212018.

Retrieved from: <https://www.washingtonpost.com/politics/ dependent-on-trade-mike-pences-hometown-takes-a-hit-due-to-trumps-tariffs/2018/07/21/25fd2bda-8c2e-11e8-8aea-86e88ae760d8_story.html?utm_term=.6b51264b7cc0>.

Access in: September 12018.

RAMAMURTI, R. \& SINGH, J. V. Emerging Multinationals in Emerging Markets. Cambridge: Cambridge University Press, 2009.

ROSENAU, J.N. Turbulence in World Politics: a Theory of Change and Continuity. Princeton: Princeton University Press, 1990.

RUGGIE, J. G. Multilateralism: the anatomy of an institution. International Organization, Vol. 46, No. 3, p. 561-598, 1992.

RUGGIE, J.G. Multilateralism matters - The theory and praxis of an institutional form. Columbia: Columbia University Press, 1993.

SALAMA, V. e BUNGE, J. Trump Administration Plans Up to $\$ 12$ Billion in Farm Aid to Ease Concerns Over Trade Disputes. Wall Street Journal, July 24 2018. Retrieved from: <https://www.wsj.com/articles/trump-says-tariffs-are-the-greatest-1532437480>. Access in: September 12018.

STUENKEL, O. Post-Western World: How Emerging Powers Are Remaking Global Order. London: Polity, 2016.

TAN, R. The U.S.-China trade war has begun. Here's how things got to this point. Wall Street Journal, July 6 2018. Retrieved from: <https://www.washingtonpost.com/news/worldviews/ wp/2018/07/05/a-timeline-of-how-the-u-s-china-trade-war-led-us-to-this-code-red-situation/?noredirect $=$ on \&utm_term $=$. a624c0b65d93>. Access in: November 12018.

TRAUB, J. Trump's Unrequited Love for Vladimir Putin. Foreign Policy, July 17 2018. Retrieved from: <https://foreignpolicy.com/2018/07/17/trumps-treason-by-father-complex/>. Access in: September 12018.
Trump and EU's Juncker pull back from all-out trade war. BBC, July 26 2018. Retrieved from: <https://www.bbc.co.uk/news/ world-us-canada-44961560>. Access in: September 12018.

VESPA, M. Stable Genius? Sorry Democrats, But This Is How China Views Trump's Foreign Policy. Townhall, July 31 2018. Retrieved from: <https://townhall.com/tipsheet/mattvespa/2018/07/31/stable-genius-sorry-democrats-but-this-is-how-china-views-trumps-foreign-policy-n2505469> Access in: September 12018.

WANG, V. W. The Logic of China-ASEAN FTA: Economic Statecraft of 'Peaceful Ascendancy'. In: LEONG, H. K. \& KU, S. C. Y. (eds.). China and Southeast Asia: Global Changes and Regional Challenges. Singapore: Institute of Southeast Asian Studies, 2005, p. 17-41.

WANG, V. W. Chindia' or Rivalry? Rising China, Rising India, and Contending Perspectives on India-China Relations. Asian Perspective, Vol. 35, No. 3, p. 437-469, 2011.

WOLFORTH, W. The Stability of a Unipolar World. International Security, Vol.24, No.1, p.5-41, 1999.

ZUMBRUN, J. What the U.S.-Mexico Trade Pact Says. Wall Street Journal, August 27 2018. Retrieved from: <https://www.wsj.com/articles/what-the-u-s-mexico-trade-pact-says-1535403635>. Access in: September 12018. 